\title{
Migraine in Children and its Relationship to Biomarkers
}

\author{
Anika Naeem* \\ Graduate, Allama Iqbal Medical College, Pakistan
}

Submission: November 22, 2018; Published: December 14, 2018

*Corresponding author: Anika Naeem, Graduate, Allama Iqbal Medical College, Lahore, Pakistan

\section{Introduction}

Migraine is a clinical manifestation of severe, recurrent and most commonly disabling headache disorder in children and adolescents which is associated with nausea and sensitivity to light and sound. Primary headache disorders such as migraine begin as early as childhood or adolescence and the prevalence increases during primary school and adolescence [1]. It is very commonly encountered by neurologists. Bio-psycho-social factors play a vital role in migraine and sometimes it is triggered by factors. Triggers that induce migraine are stress [2], fatigue, various foods, alcohol, drugs, smoking, weather changes, and odors [3]. Migraine is diagnosed clinically.

\section{Pathogenesis}

Migraine is a primary brain disorder with abnormalities in pain modulating systems and cortical stimulus processing. Migraine is thought to be a consequence of cortical hypersensitivity, cortical hyperactivity and lack of habituation. Migraine with aura has been specified as a risk factor for vascular disorder. Mast cells perivascular area linked to dura in neurons can be triggered by trigeminal nerve, sphenopalatine ganglion and neuropeptides which leads to secretion of vasoactive mediators thus contributing to pathogenesis of migraine. As far as genetic makeup is concerned, T/T genotype, MTHFR T/T homozygosity [4], TSPAN2 single nucleotide polymorphisms (SNPs) rs12134493 and rs2078371 are thought to be involved in pathogenesis of migraine. Familial Hemiplegic Migraine (FHM) subtype 3 is caused by mutations in SCN1A mutation [5].

\section{Association, Diagnosis and Treatment}

Conditions thought to be comorbid with migraine includes asthma, anxiety, depression and other chronic pain conditions. ADHD, insomnia, allergic disease2018, obesity Eidlitz, narcolepsy [6-10], cognitive defects, epilepsy, olfactory hallucination, cyclic vomiting syndrome, tumor of the hypothalamic-pituitary region, overdose of glucocorticoids or growth hormone and sickle cell disease are associated with migraine [11-16]. Migraine is diagnosed clinically but measurement of VEP visual evoked potential latency and amplitude is a reliable test for the diagnosis of migraine in children with vague symptoms [17]. Sometimes MRI of pediatric patients with migraine can show structural changes such as grey matter atrophy of frontal and temporal lobes and increased volume of the right putamen. The left fusiform gyrus had an increased volume in patients with aura whereas it was significantly atrophied in patients without aura [18].

Avoiding triggers, providing cool and calm environment, analgesic and abortive therapies are usually used to treat migraine in children. CGRP monoclonal antibodies [19] are an innovative therapy for migraine. Stress management therapies have been reported to be effective in reducing headache related disabilities in teens. Hybrid cognitive-behavioral therapy is feasible option for youth with co-occurring chronic migraine and insomnia. Two mind-body techniques, transcendental meditation or hypnotherapy and progressive muscle relaxation exercises are equally effective in reducing primary headache in children [20].

\section{Biomarkers}

Biomarkers are substances released in response to some particular phenomena taking place inside the organism. It is a partially discovered territory in field of medicine and has a lot to offer. Biomarkers are also playing a vital role in determining pathogenesis and diagnosis of migraine as well as in studying the treatment response of different migraine therapies. MicroRsNA (miRNAs) are small molecules which regulates immune and neuronal processes has been reported in patients with migraine and ischemic stroke. These MicroRsNAs can be used as an indicator of precocity for clinical and/or pharmacological intervention of migraine [21]. Migraine is a clinical diagnosis is it is very challenging to pick it in infants and juvenile population. MiR-590-5p which is a biomarker for general pain, can be used to diagnose the migraine and to biomarker of general pain and to evaluate the efficacy of the drug treatment [21]. Recurrent and severe headache in children and adolescents make them vulnerable to long term vascular morbidity and is associated with increase body mass index, C-reactive protein and homocysteine levels and decreased serum red blood cells and folate levels [22].

A direct relation between childhood migraine attacks and increased production of glial S100beta protein [23] has been established and it may be a useful biochemical marker for migraine in acute recurrent headache in childhood. Studies on biomarkers 


\section{Open Access Journal of Neurology \& Neurosurgery}

have provided information regarding pathogenesis of migraine. Oxidative stresses effect native thiol levels in body. Native thiol levels are remarkably higher in patients suffering from migraine. This might support the notion that oxidative stress has a role in pathogenesis of migraine. Elevation in s100b levels occurs during migraine attack but the peak is detected in the pain-free period after 2-4 days. Neuron specific enolase levels decrease during migraine [24]. This supports the idea of disruption of blood brain barrier during and after migraine attack. Children with migraine present with the higher levels of anticardiolipin antibody [2527] but the mean values were within the normal range. The role of anticardiolipin antibody in pathogenesis of migraine remains unclear.

\section{References}

1. Blankenburg M, Schroth M, Braun S (2018) [Chronic Headache in Children and Adolescents]. Klin Padiatr.

2. Kemper KJ, Heyer G, Pakalnis A, Binkley PF (2016) What Factors Contribute to Headache-Related Disability in Teens? Pediatr Neurol 56: 48-54.

3. Mayans L (2018) Headache: Migraine. FP Essent 473: 11-16.

4. Orsini A, Sammartino I, Valetto A, Bertini V, Marchese P, et al. (2018) Methylenetetrahydrofolate reductase polymorphism (MTHFR C677T) and headache in children: a retrospective study from a tertiary level outpatient service. Ital J Pediatr 44(1): 106.

5. Fan C, Wolking S, Lehmann-Horn F, Hedrich UB, Freilinger T, et al. (2016) Early-onset familial hemiplegic migraine due to a novel SCN1A mutation. Cephalalgia 36(13): 1238-1247.

6. Kutuk MO, Tufan AE, Guler G, Yalin O0, Altintas E, et al. (2018) Migraine and associated comorbidities are three times more frequent in children with ADHD and their mothers. Brain Dev 40(10): 857-864.

7. Cheraghi F, Shamsaei F, Fayyazi A, Molaaei Yeganeh F, Roshanaei G (2018) Comparison of the Quality of Sleep and Intensity of Headache between Migraine, Tension Headache, and Healthy Children. Iran J Child Neurol 12(4): 45-54.

8. Wei CC, Lin CL, Shen TC, Chen AC (2018) Children with allergic diseases have an increased subsequent risk of migraine upon reaching school age. J Investig Med 66(7): 1064-1068.

9. Eidlitz Markus T, Toldo I (2018) Obesity and Migraine in Childhood. Curr Pain Headache Rep 22(6): 42.

10. Yang CP, Hsieh ML, Chiang JH, Chang HY, Hsieh VC (2017) Migraine and risk of narcolepsy in children: A nationwide longitudinal study. PLoS One 12(12): e0189231.

11. Termine C, Bartoli B, Agosti MA, Cavanna AE, Balottin U (2018) Cognitive Impairment in Children and Adolescents With Migraine. Front Neurol 9: 667.

12. Jancic J, Djuric V, Hencic B, van den Anker JN, Samardzic J (2018) Comorbidity of Migraine and Epilepsy in Pediatrics: A Review. J Child Neurol33(12): 801-808.
13. Agessi LM, Villa TR (2018) Vestibular Migraine with Visual Aura and Olfactory Hallucination in Children: Two Case Reports. Neuropediatrics 49 (6): 414-416.

14. Kovacic K, Sood M, Venkatesan T (2018) Cyclic Vomiting Syndrome in Children and Adults: What Is New in 2018? Curr Gastroenterol Rep20 (10): 46.

15. Weitz R (2004) Endocrine aspects of headaches in children and adolescents. Pediatr Endocrinol Rev 1(3): 331-333.

16. Dowling MM, Noetzel MJ, Rodeghier MJ, Quinn CT, Hirtz DG, et al. (2014) Headache and migraine in children with sickle cell disease are associated with lower hemoglobin and higher pain event rates but not silent cerebral infarction. J Pediatr 164(5): 1175-1180.

17. Unay B, Ulas UH, Karaoglu B, Eroglu E, Akin R, et al. (2008) Visual and brainstem auditory evoked potentials in children with headache. Pediatr Int 50(5): 620-623.

18. Rocca MA, Messina R, Colombo B, Falini A, Comi G, et al. (2014) Structural brain MRI abnormalities in pediatric patients with migraine. J Neurol 261(2): 350-357.

19. Levin M, Silberstein SD, Gilbert R, Lucas S, Munsie L, et al. (2018) Basic Considerations for the Use of Monoclonal Antibodies in Migraine. Headache 58(10): 1689-1696.

20. Jong MC, Boers I, van Wietmarschen HA, Tromp E, Busari JO, et al (2018) Hypnotherapy or transcendental meditation versus progressive muscle relaxation exercises in the treatment of children with primary headaches: a multi-centre, pragmatic, randomised clinical study. Eur J Pediatr.

21. Gallelli L, Cione E, Caroleo MC, Carotenuto M, Lagana P, et al. (2017) microRNAs to Monitor Pain-migraine and Drug Treatment. Microrna 6 (3): 152-156.

22. Nelson KB, Richardson AK, He J, Lateef TM, Khoromi S, et al. (2010) Headache and biomarkers predictive of vascular disease in a representative sample of US children. Arch Pediatr Adolesc Med 164(4): 358-362.

23. Papandreou O, Soldatou A, Tsitsika A, Kariyannis C, Papandreou T, et al. (2005) Serum S100beta protein in children with acute recurrent headache: a potentially useful marker for migraine. Headache 45(10): $1313-1316$

24. Teepker M, Munk K, Mylius V, Haag A, Möller JC, et al. (2009) Serum concentrations of s100b and NSE in migraine. Headache 49(2): 245252.

25. Pilarska E1, Lemka M, Bakowska A (2006) [Antiphospholipid antibodies in children with migraine]. Neurol Neurochir Pol 40(4): 291-296.

26. Gallelli L, Siniscalchi A, Carotenuto M, Caroleo MC, Cione E, et al. (2017) microRNAs-based Predictor Factor in Patients with Migraine-ischemic Stroke. Microrna 6(1): 17-21.

27. Gumusyayla S, Vural G, Bektas H, Neselioglu S, Deniz O, et al. (2016) A novel oxidative stress marker in migraine patients: dynamic thioldisulphide homeostasis. Neurol Sci 37(8): 1311-1317. 
This work is licensed under Creative Commons Attribution 4.0 Licens

DOI: 10.19080/OAJNN.2018.09.555764
Your next submission with Juniper Publishers will reach you the below assets

- Quality Editorial service

- Swift Peer Review

- Reprints availability

- E-prints Service

- Manuscript Podcast for convenient understanding

- Global attainment for your research

- Manuscript accessibility in different formats

( Pdf, E-pub, Full Text, Audio)

- Unceasing customer service

Track the below URL for one-step submission https://juniperpublishers.com/online-submission.php 